Voume :19, Nomor : 1

ISSN Online : 2613-9340

ISSN Offline : 1412-1255

\section{Analisis Atas Keabsahan Perkawinan Beda Agama}

oleh :

\section{Hamdan Nasution ${ }^{1}$}

\begin{abstract}
Marital status of different religions in the legal system in Indonesia is illegitimate. Marriage Law Number 1 of 1974 in Article 2 paragraph 1 reveals that marriage is legal if it is carried out according to the law of each religion and belief. It means that marriage can only take place if the parties (future husband and wife) follow the same religion.
\end{abstract}

From the formulation of Article 2 paragraph 1, there are no marriages outside their respective laws and beliefs. Interfaith marriages are held abroad.

Keywords: Analysis, Legitimacy, Interfaith Marriage

\section{Abstrak}

Kedudukan perkawinan beda agama dalam sistem hukum di Indonesia adalah tidak sah. Undang-Undang Perkawinan Nomor 1 Tahun 1974 dalam Pasal 2 ayat 1 mengungkapkan perkawinan adalah sah apabila dilakukan menurut hukum masing-masing agama dan kepercayaannya. Berarti perkawinan hanya dapat dilangsungkan bila para pihak (calon suami dan istri) menganut agama yang sama.

Dari perumusan Pasal 2 ayat 1 ini tidak ada perkawinan di luar hukum masing-masing dan kepercayaannya itu.2.Adanya pelaksanaan perkawinan beda agama di luar negeri, seperti di negara Singapura secara formil sah menurut ketentuan-ketentuan hukum Singapura.

Kata Kunci : Analisis, Keabsahan, Perkawinan Beda Agama

\footnotetext{
${ }^{1}$ Dosen LLDIKTI dpk Fakultas Hukum UISU
}

\section{PENDAHULUANA}

\section{A. Latar belakang.}

Perkawinan adalah ikatan lahir batin antaraseorang pria dengan seorangwanita sebagai suami istri dengan tujuan membentuk keluarga (rumah tangga) yang bahagia dan bekal berdasarkan Ketuhanan Yang Maha Esa. ${ }^{2}$ Perkawinan tidak hanya berkaitan dengan hubungan pribadi dari pasangan yang melangsungkan perkawinan saja, perkawinan berkaitan juga dengan permasalahan Agama, permasalahan sosial dan permasalahan hukum. Permasalahan Agama yang menyangkut perkawinan, dapat kita lihat bahwa dalam setiap Agama tentunya mempunyai ketentuanketentuan yang mengatur masalah perkawinan, sehingga pada prinsipnya diatur dan tunduk pada ketentuan-ketentuan dari Agama yang dianut oleh pasangan yang akan melangsungkan perkawinan. Permasalahan sosial yang berkaitan dengan perkawinan, adalah merupakan cara pandang masyarakat pada umumnya mengenai pelaksanaan perkawinan, yang akan membawa dampak tertentu pada pasangan yang akan melangsungkan perkawinan dalam lingkungan masyarakatnya. Dari sudut pandang hukum, perkawinan terjadi disebabkan oleh adanya hubungan antar manusia, dari hubungan antar manusia untuk membentuk suatu ikatan pekawinan inilah menyebabkan timbulnya suatu perbuatan hukum.Perkawinanyang didasari ikatan lahir batin dapat dikatakan sah, jika telah memenuhi unsur dalam Pasal2 ayat (1) Undang-Undang Nomor1 Tahun 1974 tentang

2. Pengertian Perkawinan berdasarkanPasal 1 Undang-Undang No. 1 Tahun 1974 tentang Perkawinan 
Media Komunikasi dan Informasi Hukum dan Masyarakat

Perkawinan, perkawinan adalah sah, apabila dilakukan menurut hukum masing-masing agamanya dan kepercayaannya itu. Hal ini berarti bahwa setiap warga Negara Indonesia yang akan melakukan perkawinan sudah seharusnya melewati lembaga agamanya masing-masing dan tunduk kepada aturan pernikahan agamanya. Di dalam penjelasan Pasal2 ayat (1) Undang-Undang Nomor1 Tahun 1974 tentang Perkawinan disebutkan, bahwa tidak ada perkawinan di luar hukum masingmasing agamanya dan kepercayaannya itu, sesuai dengan Undang-Undang Dasar 1945. Dari hal tersebut dapat disimpulkan, bahwa Perkawinan mutlak harus dilakukan menurut hukum masing-masing agamanya dan kepercayaannya itu, kalau tidak, maka Perkawinan itu tidak sah. ${ }^{3}$

Pada umumnya setiap orang menginginkan pasangan hidup yang seagama. Bukan sengaja membeda-bedakan atau mendirikan dinding pemisah antara Agama yang satu dengan Agama yang lain, namun diharapkan membangun keluarga berdasarkan satu prinsip tentunya diharapkan akan lebih mudah danpermasalahan perbedaan Agama tidak perlu muncul dalam rumah tangga. Namun tidak sedikit pula pasangan yang akan melakukan pernikahan dengan perbedaan keyakinannya, hal itu dapat dimungkinkan karena adanya pergaulan antar manusia yang tiada batas. Dengan alasan tersebut tidak dapat dipungkiri bahwa perkawinan antar agama, menjadi hal yang semakin umum di lingkungan masyarakat.Perkawinan yang sah harus dicatat menurut peraturan perundang-undanganyang berlaku hal ini diatur di dalam Pasal 2 ayat (2) Undang-Undang Nomor 1 Tahun 1974 tentang

\footnotetext{
${ }^{3}$ Wantjik K Shaleh, Hukum Perkawinan Di Indonesia, Ghalia Indonesia, Jakarta, 1982, hlm16.
}

Perkawinan, menentukan“tiap-tiap perkawinan dicatat menurut peraturan perundang-undangan yang berlaku". Perbuatan pencatatan itu tidaklah menentukan sahnya suatu perkawinan, tetapi menyatakan bahwa peristiwa itu memang ada dan terjadi, jadi semata-mata bersifat administrative. ${ }^{4}$

Dengan melihat fenomena yang terjadi akhir-akhir ini, di mana pasangan yang berbeda agama melangsungkan pernikahan dan masih memegang teguh pada agamanya masingmasing, maka akan timbul masalah dalam pencatatannya di kantor catatan sipil, hal ini dikarenakan belum adanya peraturan yang mengatur masalah perkawinan beda Agama. Belum adanya peraturan yang mengatur dalam hal pencatatan perkawinan beda agama memicu keraguan dalam prosedur dan kewenangan pelaksanaan pencatatan perkawinan beda Agama.Dengan demikian, selain perkawinan harus dilakukan didepan pegawai pencatat perkawinan dan dicatatkan, terdapat tiga pilihan hukum bagi sahnya perkawinan. Ini berarti bagi orang-orang Islam misalnya, terbuka kemungkinan melangsungkan perkawinan tanpa menggunakan hukum Perkawinan Islam. Hal ini sering terjadi pada kasus-kasus perkawinan antara umat berlainan Agama. Pengertian semacam inilahyang tidak bisa diterima oleh Umat Islam. Sebab, menurut hukum Islam, sahnya perkawinan adalah kalau dipenuhi rukun nikah, di antaranya adanya Aqad Nikah berupa ljab Kabul yang dilakukan oleh pihak mempelai laki-laki dan disaksikan oleh dua orang 4 saksi. $^{5}$ Pencatatan perkawinan fungsinya hanyalah sekedar memenuhi kebutuhan Administrasi. Mengenai status

\footnotetext{
${ }^{4}$ Ibid, hlm. 17.

${ }^{5}$ Sajuti Thalib, Hukum Kekeluargaan Indonesia,(Jakarta: UI Press, Cet. 5, 1986), hlm.63
} 
Media Komunikasi dan Informasi Hukum dan Masyarakat

hukum pencatatan ini dalam hubungannya dengan Hukum Islam, akan diuraikan pada bagian tersendiri dibelakang.

\section{B. Rumusan Masalah.}

1. Bagaimana Kedudukan Perkawinan Beda Agama Menurut Undang-Undang?

2. Bagaimana kedudukan perkawinan beda agama yang dilangsungkan di luar negeri dalam sistem hukum di Indonesia.?

\section{Metode Penelitian}

Penelitian ini menggunakan jenis penelitian yuridis normatif. Penelitian yuridis normatif dilakukan dengan cara menelaah dan menginpretasikan hal-hal yang bersifat hubungan antar manusia untuk membentuk suatu ikatan pekawinan inilah menyebabkan timbulnya suatu

perbuatan hukum.Perkawinanyang didasari ikatan lahir batin dapat dikatakan sah, jika telah memenuhi unsur dalam Pasal2 ayat (1) Undang-Undang Nomor1 Tahun 1974 tentang Perkawinan

Dalam menarik kesimpulan penulis menggunakan metode dedukatif yaitu merupakan cara berfikir yang menarik kesimpulan dari suatu pernyataan atau dalil yang bersifat umum menjadi suatu pernyataan yang bersifat khusus.

\section{PEMBAHASAN}

A. Analisis Atas Keabsahan Perkawinan Beda Agama

Undang-undang Perkawinan Nomor 1 Tahun 1974 adalah hasil suatu usaha untuk menciptakan hukum nasional. la merupakan produk hukum pertama yang memberikan gambaran yang nyata tentang kebenaran dasar asasi kejiwaan dan kebudayaan "bhineka tunggal ika", dan ia juga merupakan unifikasi yang unik dengan menghormati secara penuh adanya variasi berdasarkan Agama dan kepercayaannya itu. Dalam Undang-undang ini perkawinan dibatasi dengan baik sebagai "ikatan lahir batin antara seorang pria dan seorang wanita sebagai suami istri dengan tujuan untuk membentuk keluarga (rumah tangga) yang bahagia kekal berdasarkan Ketuhanan Yang Maha Esa. Dan untuk sampai kepada sahnya suatu perkawinan, Undangundang menentukan harus menurut hukum masing-masing agama dan kepercayaannya itu. Artinya bagi Umat Islam perkawinan adalah sah, apabila dilakukan menurut hukum perkawinan Islam. Demikian pula bagi penganut Agama yang lain yang diakui di Indonesia.Dengan adanya penunjukan langsung hukum Agama dan kepercayaanya itu sebagai syarat material sahnya suatu perkawinan berarti Undangundang Perkawinan itu telah menentukan. Keadaan demikian sebenarnya merupakan kebalikan dari teori resepsi sebagai 5 warisan politik hukum Hindia Belanda, yang menyatakan bahwa hukum Agama Islam baru dapat berlaku apabila telah diresepsi kedalam hukum Adat. Dengan demikian berlakunya hukum Islam bukan lagi berdasarkan kepada teori resepsi itu melainkan ia berdasarkan langsu ng kepada Pasal 2 ayat (1) Undang-undang Perkawinan Tahun 1974. Sanksi moral saja alias sanksi akhirat, tidak selalu cukup untuk menjadikan orang takut melanggar ketentuan hukum Agama. Jadi perlu Undang-Undang dengan sangsi duniawi. Dan pendapat ketiga datang dari golongan non muslim (kelompok Nasrani) yang keberatan kalau ada Undang-Undang yang bedasarkan Agama. Mengenai sistem Undang-undang Perkawinan yang di kehendaki pada saat proses pembentukannya terbagi atas tiga aliran : Aliran pertama menghendaki satu 
Media Komunikasi dan Informasi Hukum dan Masyarakat

undang-undang yang berlaku untuk semua (unifikasi);b.Aliran kedua menghendakiagar masing-masing golongan mempunyai undangundang sendiri (diferensiasi)c.Aliran ketiga yang mengiginkan ada undang-undang pokok yang berlaku umum, selanjutnya bagi masing-masing golongan diadakan Undang-undang Organik (diferensiasi dalam unifikasi). RUUP yang diajukan tahun 1973 menganut aliran pertama (unifikasi), sedangkan RUUP sebelumnya (1967 dan 1968) menganut aliran ketiga (diferensiasi dalam unifikasi). Bagaimana dengan keinginan dari politik hukum Indonesia sendiri terhadap sistem hukum itu? Untuk mengetahui politik hukum itu perlu dilihat Garis-garis Besar Haluan Negara (GBHN). Dalam GBHN disebutkan bahwa "peningkatan dan penyempurnaan pembinaan pembinaan Hukum Nasional dengan antara lain mengadakan pembaharuan, kodifikasi, serta unifikasi hukum dalam bidangbidang tertentu dengan jalan memerhatikan "kesadaran hukum dalam masyarakat" .

Memerhatikan kesadaran hukum dalam masyarakat, berarti memerhatikan kebinekaan hukum yang ada dalam kehidupan masyarakat. Dalam pengertiannya yang sama, Ismail Saleh sebagai menteri kehakiman memberikan penjelasan sebagai berikut:"walaupun unifikasi hukum merupakan tujuan kita, akan tetapi demi keadilan, Hukum Nasional yang akan kita wujudkan bersama ini masih harus memerhatikan perbedaan latar belakang sosialbudaya dan perbedaan kebutuhan hukum yang dimiliki oleh kelompok-kelompok tertentu" .Perkawinan yang dilakukan di kalangan umat Islam langsung berpedoman kepada kitab-kitab fikih sebagai hasil ljtihad atau hasil pemikiran tokoh-tokoh fikih abad ketujuh Masehi. Karena kitab fikih tersebut adalah hasil pemikiran manusia, maka wajar apabila terdapat perbedaan pendapat di antara kitab fikih tersebut. Timbulnya perbedaan pendapat itu ada kalanya disebabkan oleh banyaknya nash Qur"an dan Hadits yang tidak berisi suatu pengertian yang jelas (qath"i) melainkan bersifat kemungkinan-kemungkinan (dhani) sehingga perlu penafsiran, dan juga dapat disebabkan karena faktor lingkungan sosial dengan segala persoalan yang berbeda. Iman Malik yang hidup di Madinah tidak mengalami apa yang dialami oleh Iman Hanafi di Irak. Kalau lingkungan sosial berbeda maka pendirian dalam menilai sesuatu kepentingan dan motif penetapan hukum juga berbeda.

\section{B. Perkawinan Beda Agama.}

Menurut Undang-Undang lalu bagaimana hukum pernikahan beda agama menurut Undang-Undang Perkawinan yang berlaku di Indonesia? Menurut UU No. 1 Tahun 1974 tentang Perkawinan, yang dalam pasal 1 menyatakan: "Perkawinan adalah ikatan lahir batin antara seseorang pria dan seorang wanita sebagai suami istri dengan tujuan membentuk keluarga (rumah tangga) yang bahagia dan kekal berdasarkan Ketuhanan Yang Maha Esa". Selanjutnya dalam pasal 2 ayat 1 dinyatakan: "Perkawinan adalah sah apabila dilakukan menurut hukum masing-masing agama dan kepercayaan itu".Dalam penjelasan atas Pasal 1 disebutkan: Sebagai negara yang berdasarkan Pancasila, dimana sila pertama adalah Ketuhanan Yang Maha Esa, maka perkawinan mempunyai hubungan yang erat sekali dengan agama/kerohanian, sehingga perkawinan bukan saja mempunyai unsur lahir/jasmani, tetapi unsur batin/rohani juga mempunyai peranan yang penting. Membentuk keluarga yang bahagia rapat hubungan dengan keturunanyang merupakan tujuan perkawinan, pemeliharaan 
Media Komunikasi dan Informasi Hukum dan Masyarakat

dan pendidikan menjadi hak dan kewajibanorang tua.

\section{Kedudukan Perkawinan Beda Agama.}

Yang dilangsungkan di Luar Negeri dalam sistem Hukum di Indonesia.1.Sahnya perkawinan Pengertian perkawinan dalam Undang-Undang No.1 Tahun 1974 tentang Perkawinan, telah memberikan suatu ketentuan yang bersifat Nasional. Dalam kaitannya menyaring berbagai persepsi yang selama ini berkembang dalam membuat pengertian perkawinan yang timbul dari pluralisme dalam masyarakat Indonesia yang berkaitan dalam masalah hukum keluarga, khususnya dalam hukum perkawinan. Undang-Undang Perkawinan, yang memuat mengenai sahnya perkawinan secara materil dalam Pasal 2 ayat (1) dan secara formil dalamPasal 2 ayat (2), maka secara Nasional mengenai sahnya perkawinan tersebut berlaku bagi seluruh masyarakat Indonesia. ${ }^{6}$

Di Berlakukanya Undang-Undang Perkawinan yang bersifat nasional ini, secara perlahan telah berpengaruh dalam hal proses perkawinan. Serta membatasi berlakunya ketentuan hukum adat menyangkut perkawinan, apabila ada yang bertentangan dengan ketentuan Hukum Agama danketentuan Perundang-undangan dalam bidang Hukum Agama. Oleh karena itulah, Hukum Adat yang biasanya berpengaruh dalam pelaksanaan proses perkawinan, semakin banyak ditinggalkan. Kesulitan dalam pelaksanaan perkawinan menurut adat, serta besarnya pengaruh Hukum Agama, baik Islam, Nasrani (Katolik maupun Protestan), ataupun Hindu dan

\footnotetext{
${ }^{6}$ Nurdin Ilyas, Pernikahan yang suci, Berdasarkan Tuntutan Agama, Bintang Cemerlang Yogyakarta ,2000, hlm. 13
}

Budha, yang kemudian diserap oleh UndangUndang Perkawinan memperbesar pergeseran pelaksanaan proses perkawinan. ${ }^{7}$

\section{Syarat Perkawinan.}

Suatu perkawinan yang sah, selain memenuhiketentuan Pasal 2 ayat (1) dan ayat (2), maka harus pula memenuhi syarat-syarat perkawinan, baik materil maupun formil, yang oleh Undang-Undang. Syarat-syarat perkawinan yang dimaksud adalah terdiri dari:

a. Syarat Materil (Menurut Undang-Undang Perkawinan)1.Perkawinan harus dengan persetujuan kedua mempelai (Pasal 6 ayat (1)guna menghindari terjadinya pemaksaan perkawinan.

b. Bagi seorangtelah diizinkan melakukan perkawinan pada usia 19 tahun sedangkan wanita 16 tahun (Pasal 7 ayat (1)), kecuali jika terdapat. penyimpangan dapat dimintakan dispensasi kepada Pengadilan atau pejabat lain yang ditunjuk (Pasal 7 ayat (2)). Bagi yang berusia belum mencapai 21 tahun, sesuai ketentuan Pasal 6 ayat (1), harus mendapat izin dari kedua orangtua (kecuali kalau salah seorang telah meninggal dunia atau tidak mampu menyatakan kehendak, maka dapat diwakilkan oleh orangtua yang masih ada) atau wali (jika kedua orangtuanya sudah tidak ada).

c. Ketiadaan halangan perkawinan sesuai dengan ketentuan Pasal 8, yaitu karena hubungan darahyang sangat dekat, hubungan semenda, hubungan susuan, hubungan saudara dengan istri atau bibi atau kemenakan dari istri (dalam hal

\footnotetext{
${ }^{7}$ Bahder Johon Nasution dan Sri Wirijati, Hukum Perdata Islam, Kompetensi Peradilan Agama, Tentang Perkawinan, Waris, Wasiat, Hibah, Wakaf dan shodaqah, Mandar Maju, Bandung, 1997, hlm12.
} 
Media Komunikasi dan Informasi Hukum dan Masyarakat

poligami), hubungan yang oleh agamanya atau peraturan lain yang berlaku terdapat suatu larangan. Seseorang yang masih terkait perkawinan dengan orang lain, tidak dapat kawin lagi kecuali karena izin Pengadilan, sesuai Pasal 9.4.Suami istri yang melakukan cerai untuk kedua kalinya, maka tidak boleh ada perkawinan lagi sepanjang tidak ditentukan lain oleh hukum agama dan kepercayaannya, sesuai dengan Pasal 10.5.Bagi seorang wanita yang putus perkawinannya berlaku jangka waktu tunggu, untuk dapat melangsungkan perkawinan baru, sesuai ketentuan Pasal 11.

d. Syarat Formil. Syarat formil ini berkaitan dengan hal mengenai tatacara pelaksanaan perkawinan (Pasal 12 Undang-Undang Perkawinan), yang diatur dalam Pasal 10 dan 11 Peraturan Pemerintah. Nomor 9 Tahun 1975.Pengaturan Perkawinan Beda Agama Dalam Hukum Perkawinan Indonesia Walaupun terdapat perbedaan, akan tetapi semuanya menurut materi yang sama dalam suatu pengertian perkawinan. Materi muatan yang mengandung kesamaan tersebut adalah dalam hal: 1.Subyeknya harus antara pria dan wanita,2.Timbulnya suatu ikatan

Dalam proses pengikatannya harus dilakukan sesuai dengan ketentuan atau peraturan yang berlaku dalam setiap sistem hukum tersebut, sehingga terdapat suatu pengakuan atas ikatan yang timbul.Dengan demikian terlihat secara jelas bahwa kesamaan yang terdapat dalam memberikan pengertian perkawinan itu telah pula diresepsioleh UndangUndang Perkawinan Nasional yang diberlakukan bagi seluruh masyarakat
Indonesia.Dalam penerapan Undang-Undang Nomor 1 Tahun 1974 juga tidak mengatur adanya perkawinan beda agama, selanjutnya pada Pasal 2 ayat 1 disampaikan bahwa perkawinan adalah sah, apabila dilakukan menurut hukum masing-masing agamanya dan kepercayaannya. Hal ini menunjukkan bahwa hukum agama merupakan landasan filosofis dan landasan hukum yang merupakan persyaratan mutlak dalam menentukan keabsahan perkawinan. Oleh karna dengan mendasarkan Undang-Undang Nomor 1 Tahun 1974 tidak dimungkinkan adanya perkawinan beda agama, karena pada masing-masing agama telah ada ketentuan hukum yang mengikat kepada mereka dan mengandung perbedaan yang perinsip serta tidak mungkin untuk dipersatukan.Dalam hal terjadi perkawinan antara seseorang yang beragama Protestan dengan pihak yang menganut agama lain, menurut Fridolin Ukur, maka: Mereka dianjurkan untuk menikah secara sipil dimana kedua belah pihak tetap menganut agama masing-masing. Kepada mereka diadakan pengembalaan khusus. Pada umumnya gereja tidak memberkatiperkawinan mereka. ${ }^{8}$

Wahyono Darmabrata mencatat ada empat cara yang lazim ditempuh pasangan beda agama yang akan menikah yaitu sebagai berikut :1.Meminta penetapan pengadilan terlebih dahulu. Atas dasar penetapan itulah pasangan melangsungkan pernikahan di Kantor Catatan Sipil. Tetapi cara ini tak bisa lagi dilaksanakan sejak terbitnya Keppres No.12 Tahun 1983.2.Perkawinan dilangsungkan menurut hukum masing-masing agama. Perkawinan terlebih dahulu dilaksanakanya

${ }^{8}$ Zaldi Munir, Perkawinan Beda Agama Dalam Perpektif Agama-Agama,

http://Zaldym.wordpress.com/2008/07/15/perkawina n-beda-agama-dalam-perspektif-agama-agama/ 
Media Komunikasi dan Informasi Hukum dan Masyarakat

menurut hukum agama seorang mempelai (bisanya suami), baru disusul pernikahan menurut hukum agama mempelai berikutnya. Permasalahanya perkawinan mana yang dianggap sah. Jika perkawinan menurut hukum yang kedua 11(terakhir) menjadi persoalan kembali tentang status perkawinan pertama.3.Kedua pasangan menetukan pilihan hukum. Salah satu pandangan menyatakan tunduk pada hukum pasagannya. Dengan cara ini, salah seorang pasangan "berpindah agama" sebagai bentuk penunduk hukum.4.Yang sering dipakai belakangan,adalah melangsungkan perkawinan di luar negeri. Beberapa artis tercatat memilih cara ini sebagai upaya menyiasati susahnya kawin beda agama di Indonesia. $^{9}$

Apabila perkawinan beda agama tersebut dilakukan oleh orang yang beragama Islam dan Kristen, maka terjadi permasalahan mengenai pencatatan perkawinan. Apakah di Kantor Urusan Agama atau di Dinas Kependudukan dan Catatan Sipil oleh karena ketentuan pencatatan perkawinan untuk agama Islam dan di luar agama Islam berbeda. Apabila ternyata pencatatan perkawinan beda agama akan dilakukan di Dinas Kependudukan dan Catatan Sipil, maka akan dilakukan pemeriksaan terlebih dahulu apakah perkawinan beda agama yang dilangsungkan tersebut memenuhi ketentuan dalam Pasal 2 Undang-Undang Perkawinan Tahun 1974 tentang syarat sahnya suatu perkawinan. Apabila pegawai pencatat perkawinan berpendapat bahwa terhadap perkawinan tersebut ada larangan menurut Undang-Undang Nomor 1 Tahun 1974 maka ia

\footnotetext{
${ }^{9}$ Wahyono Darmabrata, Tinjauan Undang-Undang No.1 Tahun 1974 Tentang Perkawinan beserta Undang-Undang dan Peraturan Pelaksanaanya,CV. Gitama Jaya, Jakarta, 2003, hlm. 102.
}

dapat menolak untuk melakukan pencatatan perkawinan. ${ }^{10}$

Permasalahan yang mungkin terjadi, jika ternyata terjadi pemutusan perkawinan atau cerai. Kalau nanti mau cerai, apakah bisa di Pengadilan Negeri. Namun kalau luar negerinya ada yang beragama di Kantor Urusan Agama, karena diluar negeri tidak ada Kantor Urusan Agama. Diluar negeri semua perkawinan dicatatkan di catatan sipil. Kalau beragama Islam, hanya dilakukan di mesjid saja karena tidak ada Kantor Urusan Agama di luar negeri.a)Perkawinan Beda Agama Ditinjau Dari Pandangan Agama di Indonesia. Di Indonesia terdapat 5 Agama yang diakui dan banyak dianut oleh masyarakatnya, yaitu Islam, Nasrani, (Kristen Protestan dan Katholik), Hindu, dan Budha. Dan disetiap agama, adapun yang menjadi acuan dalam menganalisis permasalahan hanya 3 yang menjadi salah satu contoh diantara 5 agama tersebut yaitu; Kristen Protestan, Hindu, dan Budha. Perkawinan merupakan salah satu tujuan hidup manusia. Sehingga bisa dianggap di dalam Hukum Adat di Indonesia telah terdapat bagian-bagian dari aturan-aturan agama Nasrani, Hindu, dan Budha.1). Menurut Agama Kristen ProtestanSalah satu hal yang dianggap sebagai salah satu sendi dari agama Kristen adalah hal monogami, yaitu ketentuan bahwa seorang lakilaki tidak di perbolehkan mempunyai lebih dari seorang istri. Dan menurut agama Kristen/Nasrani. ${ }^{11}$ perkawinan adalah persekutuan hidup pria dan wanita yang monogami, yang arahkan ke pembiakan sebagai tata ciptaan Tuhan, yang disucikan Kristus.Menurut keyakinan Kristen Protestan,

\footnotetext{
${ }^{10}$ Pasal 21 ayat (1) Undang-Undang No. 1 Tahun 1974 Tentang Perkawinan.

${ }^{11}$ R. Soetjo Prawirohamidjojo, Op. Cit. hlm.3335
} 
Media Komunikasi dan Informasi Hukum dan Masyarakat

pernikahan itu mempunyai dua aspek, yaitu merupakan soal sipil yang erat hubunganya dengan masyarakat dan negara, karenanya negara berhak mengaturnya menurut undangundang negara. Kedua perkawinan adalah soal agama, yang yang harus tunduk kepada hukum agama. Dengan demikian gereja Kristen Protestan berpendapat bahwa agar perkawinan itu sah menurut hukum negara maupun hukum Tuhan, haruslah dilakukan berdasarkan baik hukum agama maupun hukum negara. ${ }^{12} 2$ ). Menurut Agama HinduHukum agama Hindu memandang perkawinan sebagai salah satu dari banyak samskra,sebagai suatu yang suci, yang diatur oleh dharma, dan harus tunduk pada dharma. Karena itu perkawinan baru sah bila ia dilakukan menurut hukum agama dengan melalui upacara sakramen yaitu wiwaha homaatau wiwaha samskara.Bila suatu perkwinan tidak dilakukan menurut hukum agama, maka segala akibat hukum timbul yang timbul dari perkawinan tersebut tidak diakui oleh agama. Dari ketentuan tersebut dapat dipahami bahwa pada hakekatnya hukum agama Hindu juga tidak mengenal adanya perkawinan antar agama.3). Menurut Agama BudhaPerkawinan antar agama di mana salah seorang calon mempelai tidak beragama Budha, menurut keputusan Sangha Agung Indonesia diperbolehkan, asal pengesahan perkawinannya dilakukan menurut cara agama Budha.

Dalam hal ini calon mempelai yang tidak bergama Budha, tidak diharuskan untuk masuk agama Budha terlebih dahulu. Akan tetapi dalam upacara ritual perkawinan, kedua mempelai diwajibkan mengucapkan "atas nama

12 Lemata Tarigan, Perkawinan Antar Agama Ditinjau dari Undang-Undang Perkawinan No. 1/1974,makalah sebagai tugas dalam mata kuliah Kapita Selekta Hukum Adat pada Program Studi S2 Ilmu Hukum, PPs UU,2003.
Sang Budha, Dharma dan Sangka".Dari uraian di atas dapat disimpulkan bahwa agama Budha tidak melarang umatnya untuk melakukan perkawinan dengan penganut agama lain. Akan tetapi untuk penganut agama lainnya maka harus dilakukan menurut agama Budha. Kewajiban untuk mengucapkan atas nama Sang Budha, Dharma dan Sangka, ini secara tidak langsung berarti bahwa calon mempelai yang tidak beragama Budha menjadi penganut agama Budha, walaupun sebenarnya ia hanya menundukkan diri pada kaidah agama Budha pada saat perkawinan itu dilangsungkan.

\section{E. PENUTUP}

\section{Kesimpulan.}

1. Kedudukan perkawinan beda agama dalam sistem hukum di Indonesia adalah tidak sah. Undang-Undang Perkawinan Nomor 1 Tahun 1974 dalam Pasal 2 ayat 1 mengungkapkan perkawinan adalah sah apabila dilakukan menurut hukum masingmasing agama dan kepercayaannya. Berarti perkawinan hanya dapat dilangsungkan bila para pihak (calon suami dan istri) menganut agama yang sama.

2. Dari perumusan Pasal 2 ayat 1 ini tidak ada perkawinan di luar hukum masing-masing dan kepercayaannya itu.2.Adanya pelaksanaan perkawinan beda agama di luar negeri, seperti di negara Singapura secara formil sah menurut ketentuanketentuan hukum Singapura. Namun untuk negara Indonesia perkawinan tersebut tetap tidak sah, meskipun ada kewajiban untuk mencatatkan peristiwa perkawinan mereka. Pencatatan perkawinan ini hanya berupa pemenuhan syarat administrasi untuk memberikan status sosial kepada 
Media Komunikasi dan Informasi Hukum dan Masyarakat

masyarakat bahwa pasangan yang menikah adalah benar merupakan suami istri.

\section{SARAN}

Undang-Undang Perkawinan perlu disempurnakan sebab ada kekosongan hukum tentang perkawinan beda agama. 2.Pentingnya penyempurnaan Undang-Undang tersebut disebabkan karena beberapa hal yaitu, pertama, Undang-Undang Nomor 1 Tahun 1974 tidak mengatur perkawinan beda agama, kedua, masyarakat Indonesia adalah masyarakat plural yang menyebabkan perkawinan beda agama tidak dapat dihindarkan, ketiga, persoalan agama adalah menyangkut hak asasi seseorang, dan keempat, adanya kekosongan hukum dalam bidang perkawinan.

\section{Daftar Bacaan.}

Ahmad Azhar Basyir, Hukum Adat Bagi Umat Islam, (Yogyakarta: Nur Cahaya, 1983).

Arso Sosroatmodjo dan waisat Aulawi, Hukum Perkawinan di Indonesia,(Jakarta: Bulan Bintang, 1981).

Bahder Johon Nasution dan Sri Wirijati, Hukum Perdata Islam, Kompetensi Peradilan Agama, Tentang Perkawinan, Waris, Wasiat, Hibah, Wakaf dan shodaqah, Mandar Maju, Bandung, 1997.

Farouq Abu Zaid, Hukum Islam Antara Tradisionalis dan Modernis, a.b. Husein Muhammad, (Jakarta: P3M,1986).

Hazairin, Tinjauan mengenai UU perkawinan Nomor 1/1974, (Jakarta: Tintanas,1986).

Mohammad Daud Ali, Kedudukan Hukum Islam Dalam Sistem Hukum Indonesia, (Jakarta : Risalah, 1984).

Nurdin llyas, Pernikahan yang suci, Berdasarkan Tuntutan Agama, Bintang Cemerlang Yogyakarta ,2000.

Pluralisme Dalam Perundang-undangan Perkawinan di IndonesiaAirlangga University Press. 1988.
Sajuti Thalib, Hukum Kekeluargaan Indonesia,(Jakarta: UI Press, Cet. 5, 1986).

Wahyono Darmabrata, Tinjauan UndangUndang No.1 Tahun 1974 Tentang Perkawinan beserta Undang-Undang dan Peraturan Pelaksanaanya,CV. Gitama Jaya, Jakarta, 2003.

Wantjik K Shaleh, Hukum Perkawinan Di Indonesia, Ghalia Indonesia, Jakarta, 1982. 